\title{
Stress studies for clothing companies applying the social relationship of companies
}

DOI: 10.35530/IT.071.01.1656

\section{ABSTRACT - REZUMAT}

\section{Stress studies for clothing companies applying the social relationship of companies}

Mental healt is a major component of human health in the workplace. The phenomenon of stress felt by workers in Europe is in the order of 22\%. A study conducted by the Higher Institute of Work and Health (ISST) (2007-2009), showed that the stress in Tunisia was in the order of $17 \%$. In France the stress is $12.6 \%$ and in the United States of America (USA) is in the order of $12 \%$. In this context, the aim of this study is to use the Karazek method and the stratified sampling method to evaluate the psychosocial (PSR) and psycho-organizational risks of Tunisian staff in northern Tunisia within a grou. of 4 companies applying the method (CSR) social relationship of companies to the clothing sector and their prevalence in the sections studied. The overall average total percentage of stress at work (JOB strain) that we found is $15.4 \%$ which were distributed in 7 sections of which those with significant percentages are: the ironing which is in the order $4.8 \%$ of the Stressed population and represents $31.16 \%$ of the overall stress of the same section, the preparation accounts $3.6 \%$ of the population and $23.37 \%$ of the global stress. In order to the well-being at work, to fight against the occupational diseases, the demotivation, brain drain, the bad process of the recruitments, the sources of nonperformance, the errors of forgetfulness, the defects and the organizational attempts to reduce the percentage of stress and to bring appropriate solutions.

Keywords: mental health, Karazek, PSR, psycho-organizational, CSR, motivation.

\section{Studiu privind stresul din companiile producătoare de îmbrăcăminte care aplică metoda relațiilor sociale}

Sănătatea mintală este o componentă majoră a sănătătii umane la locul de muncă. Fenomenul de stres resimțit de lucrătorii din Europa este de 22\%. Un studiu realizat de Institutul Superior de Muncă și Sănătate (ISST) (2007-2009) a arătat că stresul din Tunisia a fost de 17\%. In Franța, stresul este de 12,6\%, iar în Statele Unite ale Americii (SUA) este de $12 \%$. In acest context, obiectivul acestui studiu este să utilizeze metoda Karazek și metoda de eșantionare stratificată pentru a evalua riscurile psihosociale (PSR) și psiho-organizaționale ale personalului din nordul Tunisiei, în cadrul unui grup din 4 companii din sectorul de îmbrăcăminte, care aplică metoda relațiilor sociale (CSR) și prevalența acestora în secțiunile studiate. Procentul mediu total de stres la locul de muncă (tulpina JOB) descoperit este de 15,4\%, care a fost distribuit în 7 secțiuni, dintre care cele cu procente semnificative sunt: activitatea de călcare, cu un procent de 4,8\% din populația stresată și reprezintă 31,16\% din stresul total al aceleiași secțiuni și activitatea de pregătire care reprezintă 3,6\% din populație și 23,37\% din stresul global. Pentru a aduce o stare de bine la locul de muncă, trebuie să se combată bolile profesionale, demotivarea, neproductivitatea, procesul necorespunzător al recrutărilor, sursele neperformanței, erorile umane, defectele, iar organizațiile trebuie să încerce să reducă procentul de stres și să aplice soluții adecvate.

Cuvinte-cheie: sănătate mintală, Karazek, PSR, psiho-organizațional, CSR, motivație

\section{INTRODUCTION}

Mental health issues are one of the leading causes of the global burden of disease, which is a challenge in effectively gather the combination of mental and physical health needs that are part of a broader problem of people with concomitant illnesses [1]. For this reason, psychosocial factors at work are recognized as risk factors for health. In this context, the Karazek questionnaire is a tool for evaluating psychosocial factors at work [2]; that allow the collective assessment of the well-being at work of groups and individuals. In addition, these elements can determine workrelated stress. On the other hand, new socio-cultural and medical knowledge has raised awareness of the role of the workplace as one of the social determinants of health [3]. In addition, psychosocial risks arise from the interaction between work content, organization, technological, environmental, workers, resources and need competencies [4]. For this its prevalence example in France, 2/3 of employees will not work carefully [5]. In Tunisia in the clothing (clothing) sector, stress was estimated at $23 \%$ [6]. This thinking led "very early" to gain both employee wellbeing and improved production by rethinking the relationship between work and health [7]. In the study of stressors, their frequency and intensity are the most important characteristics to consider [2]; Which can influence the health of workers chronically and expose them to psychosocial risks and work-related stress that can multiply and affect the human body and its organs [8-9]. In this context, the European Agency for Safety and Health at Work (EU-OSHA) 
defines work-related stress as the feeling of uneasiness and discomfort felt by workers who have to cope with demands and pressures that do not match their knowledge and ability [10]. In addition, statistics show that the prevalence of psychosocial risks and work-related stress are available to varying degrees across countries and regions. For example, 40 million people in the European Union (EU) have been affected by work-related stress. According to the report of the European Risk Observatory published in 2009, in Europe, work-related stress accounts for between $50 \%$ and $60 \%$ of all lost working days [11]. The present study is a cross-sectional exploratory study that investigates the relationship between stress and work in terms of signs and psychological traits, personality traits, learning styles, and job satisfaction in the clothing industry. The study is conducted on a pilot sample of adult employees in the Tunisian work environment who started to apply CSR (Corporate Social Responsibility) [12].

\section{METHODS OF WORK AND MATERIALS USED}

In this study, we used a participatory approach for our work in three stages [13]. Collect data in respect of confidentiality:

1) Indicators related to the operation of the company such as absenteeism less than $3 \%$, a work schedule of $8 \mathrm{~h} /$ day, the percentage of defects less than $1 \%$, labor disputes, the rate of supervision around $10 \%$, versatility, average age, average experience of company staff etc. Indicators related to the health and safety of employees, example of diseases such as MSDs "Musculoskeletal Disorder" [14-15] which is of the order of $2 \%$ for some workers declared (have MSDs) in this group of companies, exposure time etc. 2) Build the list of indicators. What needs to be done and understood by all the company's staff and establish a social dialogue with the staff of the company.

3) Put the indicators into perspective to objectify the psychosocial risks which will then be evaluated according to the level of stress, the search for causes and the risk sections and then implement a prevention action plan.

The first tool we used, the Karazek questionnaire, consists of several important determinants of the individual work environment: decision latitude, psychological demands at work, physical hardness, isometric physical load, occupational safety [16-17] and social support at work [6]. This test was of French version (Karazek R., 1998) in an anonymous way, integrating socio-demographic and professional factors, with a practical approach of the method of evaluation by using several factors age, sex, seniority married or unmarried, average number of children by age and degree of versatility; and to calculate the weightings of the scores with this model, the following scale was used: 1 to 4 , depending on the degree of satisfaction [17] (table 1).

The second tool used: The stratified sampling method: it consists in subdividing a heterogeneous population into a stratum (subgroup). This method

\begin{tabular}{|c|c|c|c|c|}
\hline \multicolumn{5}{|c|}{ SCALE ACCORDING 1} \\
\hline Appreciation & $\begin{array}{c}\text { Totally not } \\
\text { satisfied }\end{array}$ & $\begin{array}{c}\text { Not } \\
\text { satisfied }\end{array}$ & Satisfied & $\begin{array}{c}\text { Very } \\
\text { satisfied }\end{array}$ \\
\hline $\begin{array}{c}\text { Degree of } \\
\text { satisfaction }\end{array}$ & 1 & 2 & 3 & 4 \\
\hline
\end{tabular}

consists in finding in the sample the same proportions for each of the strata according to the characteristics chosen for the study in the target population. [18-20] This study used a 95\% confidence percentage and a precision rate of 0.05 .

The formulas of Karazek [14-16]:

Decisional latitude

$$
\begin{aligned}
\mathrm{DL}= & 4 \times[Q 4+(5-\mathrm{Q} 6)+\mathrm{Q}]+2 \times[Q 1+ \\
& +(5-\mathrm{Q})+\mathrm{Q} 3+\mathrm{Q} 5+\mathrm{Q} 7+\mathrm{Q} 9]
\end{aligned}
$$

(the threshold 70)

The psychological demand

$$
\begin{aligned}
P D= & Q 10+Q 11+Q 12+(5-Q 13)+Q 14+ \\
& +Q 15+Q 16+Q 17+Q 18
\end{aligned}
$$

(the threshold 21)

Social support

$$
\begin{array}{r}
\text { SS }=\text { Q23 + Q24 + Q25+ Q26 + }(5-Q 27)+ \\
+(5-\text { Q28) }+ \text { Q29 }+ \text { Q30 + Q31 + Q3 } \\
\text { (the threshold < 24) }
\end{array}
$$

The gratitude

$$
\begin{aligned}
\mathrm{Gr}= & (5-\mathrm{Q} 27)+(5-\mathrm{Q} 28)+\mathrm{Q} 29+\mathrm{Q} 30 \\
& +\mathrm{Q} 31+\mathrm{Q} 32 \quad \text { (the threshold < 15) }
\end{aligned}
$$

If the psychological demand score is greater than 21 and the decision latitude score is less than 70 , the individual is in the "stressed" area and is therefore considered to be "under stress". And if this score added to the social support score is greater than 24 we have the case of "ISO STRAIN" (figure 1).

Computer tools were also used; like XLSTATPremium, and Excel version: 2013. Regarding the CSR method; its goal is to attract and retain employees, but also to make them proud of their membership in the company, to increase financial and social performance in the following way: Develop a policy:

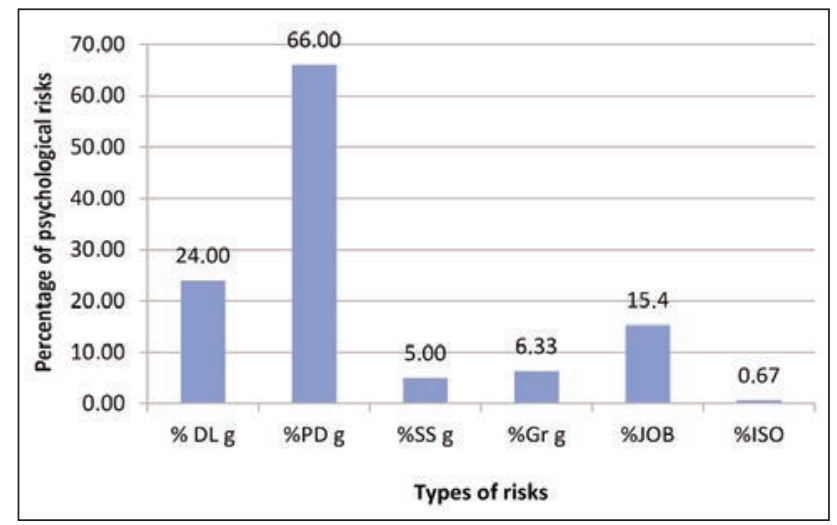

Fig. 1. Global Distribution Chart of Stress Parameters 
choose a line of work that allows to involve employees and that is meaningful within the company. Deploy a tactic Continuous improvement and measure results according to examples of measurable indicators: absenteeism rate, turnover, social and labor barometer [12] etc.

\section{RESULTS}

The decision latitude (DL) had an average value of 74.78 , a difference $( \pm 6.82$ ), a median of 74 years was high and 300 employees, which affects $24 \%$ of the workforce studied. Psychological demand (PD) with an average value of 22.56 with a difference $( \pm 2.77)$, a high median value of 23 to 21 , which is the threshold value: it represents a percentage of $66 \%$ of the studied population. The population that deserves the most social support is: $5 \%$, with a fairly high average of 28.84 compared with a threshold 24 of a median of 30 and a difference of $( \pm 2.56)$. However, $95 \%$ were satisfied. With respect to recognition, $6.33 \%$ was not achieved, compared to $93.67 \%$ with an average median of 18.2 and a median of 18 and a threshold of $>15$. We have $24 \%$ of the population studied. has a decision latitude and $66 \%$ have a strong psychological demand. We also have $5.00 \%$ who need more social support than others. In addition, $6.33 \%$ of the workforce has recognition problem. $15.4 \%$ of the workforce has a tense stress "JOB strein" and $0.67 \%$ has a job "ISO strein". All of this brings us back to talking about the percentages of psychosocial factors by sex (figure 2 ).

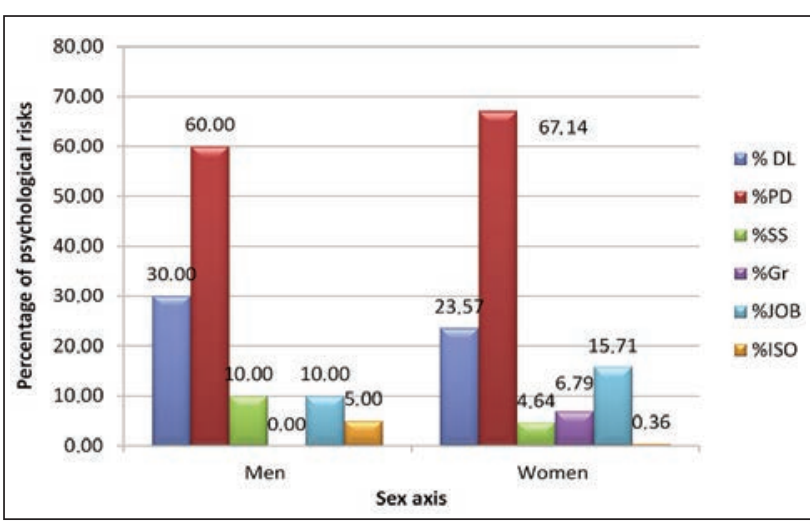

Fig. 2. Percentages of psychosocial factors by gender

According to this graph, which summarizes the study's situation for men and women: It can be emphasized that the overall decision latitude (DL) is higher for men (30\%) than for women $(21.43 \%)$. while psychological demand is the opposite; among women $(67.14 \%)$ among men (60\%). We also have $10 \%$ men and $4.64 \%$ women asking for an improvement in their social supports. With regard to recognition, a percentage of $6.79 \%$ of women and no demand in men were obtained. As we obtained a percentage of $10 \%$, which constitutes a tense work situation "JOB S TREIN". For women, the percentage is around $15.71 \%$. For ISO STREIN, the percentage obtained among men who are $5 \%$ higher than the percentage of women: $0.36 \%$. These results obtained make it possible to determine the levels of classification of the psychological risk or even table 2.

Table 2

PERCENTAGE OF RISK FACTORS PER CLASSIFICATION LEVEL

\begin{tabular}{|c|c|c|c|c|}
\hline \multirow{5}{*}{ 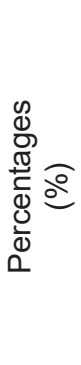 } & Relaxed & Active/dynamic & & \\
\hline & 24,67 & 44,67 & & \\
\hline & & $\Longrightarrow$ & JOB & \\
\hline & 15,01 & & 0.67 & \\
\hline & Passive & Tense Work & & \\
\hline
\end{tabular}

When the combination of DL/PD risk factors was obtained, the following percentages were obtained: $44.67 \%$ of the population is dynamic based on their positive psychological risk factors. For the passive population its percentage is $19.67 \%$ and the relaxed population has a percentage of $24.67 \%$. There is some stress due to high decision latitude and low psychological demand. We have $15.4 \%$ of the sample size of the four companies with a "high" stress risk that requires taking preventive and curative measures to minimize it. We also have $0.67 \%$ of the study population having an "ISO effect" among the following factors: $\mathrm{DL}+\mathrm{PD}+\mathrm{SS}$ of some people working with this population and communication that needs to be improved. To do this, we will focus our study and analysis on job classification levels to avoid the risk of preaching mental disorders [20] and then think of finding solutions, corrections and improvements to reduce the other two levels: Relaxed and passive to be active (table 3 ).

According to this study, there is a proportional relationship between experience, age and versatility, especially among women. More than women's early learning (age), the lower the psychological risk to the future will be when she is over 30 (see table 3 ). Example: women who have experience ( $0-10$ years) have a $9.3 \%$ stress percentage and their ages under 20 have a stress percentage $7.86 \%$ more those with a degree of versatility 5 operations have a stress percentage $9 \%$ and these percentages decrease in time and learning functions.

Note: Women over the age of 30 have been found to have tense stress "job strein" as their learning was done in an age $>20$ years.

\section{Prevalence:}

The prevalence of stress-related job stress factors in relation to the work sections is summarized in figure 3 . This graph shows that the ironing, preparation and sewing sections have the highest percentages that are prioritized to solve them and that can influence the production and quality of work because these sections have the largest population in the companies. 


\begin{tabular}{|c|c|c|c|}
\hline \multicolumn{4}{|c|}{ SUMMARY OF RISK FACTORS AS A FUNCTION OF THE PARAMETERS OF STRESS } \\
\hline No. & Risk factors & Settings & $\begin{array}{l}\text { Prevalence and percentages men and women } \\
\qquad M: \text { Men/W: Women }\end{array}$ \\
\hline 1 & Job strein & $\begin{array}{l}\text { Experience } \\
0-10 \text { years } \\
10-20 \text { years } \\
>20 \text { years }\end{array}$ & $\begin{array}{l}\text { It is around } \mathbf{5 \%} \text { for men and } \mathbf{9 . 3} \% \text { for women. It decreases with } \\
\text { time, around } 4.6 \% \text { for women and remains constant at } 5 \% \text { for } \\
\text { men. More than we are experienced, the percentage of the risk } \\
\text { decreases to } 1.43 \% \text { for both sexes } \mathrm{M} / \mathrm{W}\end{array}$ \\
\hline 2 & Job strein & $\begin{array}{l}\text { Ages } \\
<20 \text { years } \\
20-30 \text { years } \\
30-40 \text { years } \\
>40 \text { years }\end{array}$ & $\begin{array}{l}\text { It varies between } 3 \% \text { for women and } 5 \% \text { for men. It increases to } \\
7.86 \% \text { women and remains stable in men } \\
\text { * It decreases in both sexes } \mathrm{M} / \mathrm{W} \text { to } 2.83 \% \mathrm{~F} \text { and } 0 \% \mathrm{M} \\
\text { Continues to decrease towards the } 2 \% \text { for the women and } \\
\text { remains null in the men. }\end{array}$ \\
\hline 3 & Job strein & $\begin{array}{l}\text { Degree of versatility } \\
\quad *<5 \text { operations } \\
* 5-15 \text { operations } \\
{ }^{*}>15 \text { operations }\end{array}$ & $\begin{array}{l}\text { * In both sexes it is around } 5 \% \mathrm{M} / \mathrm{W} \text {. It increases in women to } \\
9 \% \text { and remains stable in men by } 5 \% \text {. } \\
\text { * The risk decreases remarkably towards } 1.4 \% \mathrm{~W} \text { and } 0 \% \mathrm{M}\end{array}$ \\
\hline 4 & Job strein & $\begin{array}{l}\text { Number of persons } \\
\text { married with children } \\
\text { and their ages } \\
\quad{ }^{*}<6 \text { years } \\
{ }^{*}>6 \text { years } \\
{ }^{*} \text { without children }\end{array}$ & $\begin{array}{l}\text { * For men is around } 5 \% \text { while among women is: } \mathbf{8 . 5 \%} \text {. } \\
{ }^{*} \text { remains stable at the men in } 5 \% \text { it decreases towards } 5.83 \% \\
\text { for the women. } \\
\text { * Null in men and low in women } 1 \%\end{array}$ \\
\hline
\end{tabular}

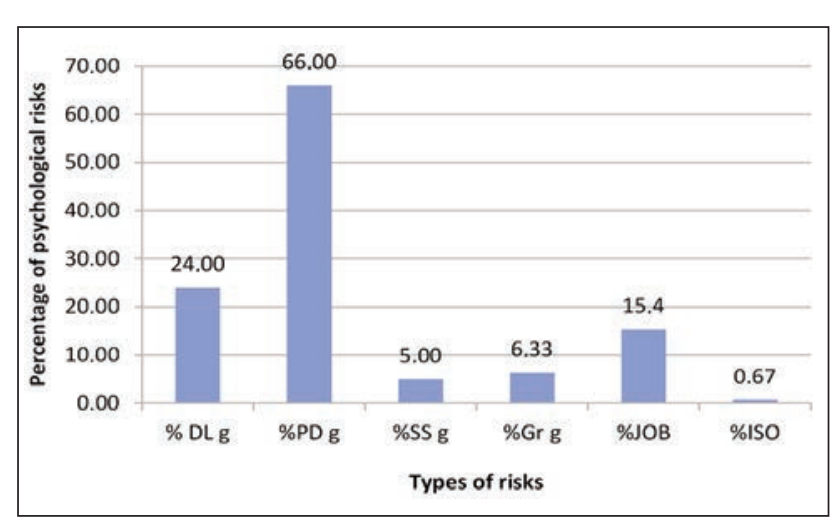

Fig. 3. Psychology risk prevalence

They represent more than $80 \%$ of the total numbers of sections affected by stress. For example; women who work in the ironing section who have experience between (0-10 years), ages between 17 and 30, married with children under 6 years are the ones who are the most stressed and they represent $64.9 \%$ of the effective with stress tense "JOB strein".

\section{DISCUSSION ON THE RESULTS}

Comparison of the results with other studies in the clothing sector in Tunisia: Stress studies in Tunisia are fairly recent and require more effort, equipment, human and financial efforts, the table below, column 2 of this study, presents new figures. In this context, it can be remarkable to reduce stress at work through the management system of these companies that apply the best possible while integrating scientific and organizational techniques for the best of each. This group of companies has a stress rate of $15.4 \%$; while for other studies tends between $17 \%$ and $23 \%$

Table 4

COMPARISON ON RISKS FACTORS

\begin{tabular}{|c|c|c|c|}
\hline \multicolumn{5}{|c|}{ COMPARISON ON RISKS FACTORS } \\
\hline $\begin{array}{c}\text { Study } \\
\text { (n) }\end{array}$ & This study & $\begin{array}{c}\text { Abidi } \\
\text { et al. [22] }\end{array}$ & $\begin{array}{c}\text { Magroun I. } \\
\text { et al. [6] }\end{array}$ \\
\hline Sector & Sewing & Sewing & Multisectorial \\
\hline Population & 300 & 322 & 954 \\
\hline Country & Tunisia & Tunisia & Tunisia \\
\hline Strength work (\%) & 15.4 & 23 & 17 \\
\hline PD (\%) & 66 & - & 41 \\
\hline PDW (\%) & 67.14 & - & 45 \\
\hline PDM (\%) & 55 & - & 40 \\
\hline DL(\%) & 24 & - & 49 \\
\hline DLW (\%) & 21.43 & - & 47 \\
\hline DLM (\%) & 30 & - & 50 \\
\hline SS (\%) & 5 & - & - \\
\hline SSW (\%) & 3.57 & - & - \\
\hline SSM (\%) & 10 & - & - \\
\hline Gr (\%) & 6.33 & - & - \\
\hline
\end{tabular}

W: Women / M: Men

$[22,6]$. In addition, only $5 \%$ of respondents are not satisfied with their social support for different parameters (communication, support of colleagues and other factors with in-depth research in psychology with other methods and tools ...) when the $95 \%$ are satisfied $80 \%$ of the population gave the karazek questionnaires a score of 4/4 (Q19, Q20, Q21) 41\% overall is due to the type of work, tasks and operations according to the sections requiring more than efforts to decrease is $24 \%$, which is lower than that developed by I. Magroun and all that was of the order of $49 \%$. 


\section{CONCLUSION AND PERSPECTIVES}

To conclude, once factors have played an important role in calculating risk factors, it is important to become familiar with research on work sections, to highlight causes and to think about solutions value. Companies in the worker/agent category are still doing more than is required for them. In addition, the company must develop cooperation with the world to achieve the objectives of the CSR project. We have the percentage of stress $15.4 \%$, women of age between 17 and 30 years old who are the most stressed because of these parameters "Aged, experience, versatility, age of their children 6 years", as well as others who deserve further study. In addition, they (women) represent $10 \%$ of the overall population and $64.9 \%$ of the workforce "JOB STREIN", while women who are older (40 years to 50 years) and started their careers early are less stressed than working conditions are favorable (wages, needs, willingness to learn ...). Based on these results, this group of companies is still thinking of developing their managerial and organizational strategy towards sustainable development projects by keeping SMART objectives on several levels: health, ergonomic safety CSR, motivation [23], quality according to priorities and the urgency of the problems while applying other tools such as $7 \mathrm{M}[21,24]$ etc. Finally, we must try to reduce the annual tension stress of $2 \%$ to obtain a maximum percentage of $5 \%$ of our objectives.

\section{REFERENCES}

[1] Naylor, C., Parsonage, M., McDaid, D., Knapp, M., Fossey, M., Galea, A., Long-term conditions and mental health the cost of co-morbidities, The King's Fund and Centre for Mental Health, ISBN: 978-1-85717-633-9, P32, 2012, London

[2] De Witte, I., Job insecurity: review of the international literature on definitions, prevalence, antecedents and consequences, In: SA Journal of Industrial Psychology, 2005, 31, 4, 1-6

[3] Greco, E., Workshop, V., Health determinants: new paths for scientific research, ISBN: 0393-5620, Higher Institute of Health, Rome, Italy, Istisan Congress 14/C2 edition, 8 May, 2014

[4] Stavroula, L., Aditya, J., Health Impact of Psychosocial Hazards at Work: An Overview, Publications of the World Health Organization, 2013, Geneva, Switzerland

[5] Gaelledu, P., The stress management toolkit, study for the institute great Place to work, February: edition dunod, ISBN 978-2-10-075832-6, February 2017, France

[6] Magrouna, I., et al., Evaluation of psycho-organizational constraints according to the Karazek model among employees of 14 Tunisian private sector enterprises, Institut de santé et de sécurité au travail, Tunis Tunisie, 2016

[7] Martini, F., Gautier, M., Souville, M., Mocaer, S., Cervantes, M.-H., The PSR Marseilles notebooks France Legal deposit: ISSN: 1772-7642, February 2005

[8] Bosma, H., Peter, R., Siegrist, J., Marmot, M., Two alternative job stress models and the risk of coronary heart disease, In: American Journal of Public Health, 1998 , 88, 1, 68-74

[9] Toivanen, S., Social determinants of stroke as related to stress at work among working women: A literature review, In: Stroke Research and Treatment, 2012, article ID 873678

[10] DeSio, S., et al., Quality of Life in Workers and Stress: Gender Differences in Exposure to Psychosocial Risks and Perceived Well-Being, In: BioMed Research International Volume, 2017

[11] Thèrese, M., Workplace stress: A collective challenge, ISBN: 978-92-2-130641-2, 2016, France

[12] Gond, J.-P., Moon, J., Kang, N., The government of self-regulation: On the comparative dynamics of corporate social responsibility, In: Economy and society, 2011, 40, 4, 640-671

[13] Maymo, V., Murat, G., The Toolkit for Sustainable Development and CSR, DUNOD Edition, ISBN: 978-2-10-0765065, 2017, France

[14] INRS, How to Detect Psychosocial Company: Indicators to Guide You, ED 6086 2nd Edition ISNB 978-2-7389, 2014

[15] Ghram, R., Fournier, C., Khalfallah, T., Six, F., Analysis of sociocultural factors and the onset of musculoskeletal disorders: the case of seamstresses in Tunisia, ISSN /1481- 9384, 2010

[16] Van Wassenhove, W., Guarnieri, F., Psychosocial risk assessment models, definition and method elements, In: CSR Risk Safety Environment, 2010, 4, 15-18

[17] Karazek, R., The job content questionnaire( JCQ): An instrument for internationally comparative assessements of psychological job characteristics, In: Journal of Occupational Health Psychology, 1998, 3, 4, 322-55

[18] Lacroix, S., Four Sampling Methods, Available on http://www.sylvainlacroix.ca/ESW/Files/306_Sampling Method.pdf (Accesed on 2018)

[19] Magnier, A., Psychosocial factors at work. An assessment by the Karazek questionnaire in the Sumer 2003 survey, In: First information and first syntheses, 2008, 1-8, 22, France, ISSN 1253-1545

[20] Stanfeld, S., Candy, B., Psychosocial work environment and mental health - A meta-analytic review., In: Scand J Work Environ Heath, 2006, 32:443-62

[21] Facchin, E.D., The Problem Treatment Methods Toolbox, Science, Technology, Health .Joseph Fourier University Grenoble France, Available on http://applis.cermav.cnrs.fr/ANGD_qualite_en_chimie/Facchin.pdf (Accessed on 15-05-2018) 
[22] Abidi, A.B., Mansour, H., Nouaigui, H, et al., Contribution to the evaluation of stress at work: about a cross-sectional study carried out in a garment factory in the silliana region, In: Health and safety at work magazine, 2007, P42, Tunisia

[23] Thomas, L., Micheau-Thomazeau, S., The motivation toolbox, DUNOD Edition, ISBN: 978-2-10-071615-9), 2015, Paris, France

[24] Luca, L., A new model of Ishikawa diagram for quality assessment, 20th Innovative Manufacturing Engineering and Energy Conference (IManEE 2016) IOP Publishing IOP Conf. Series: Materials Science and Engineering 161, 2016

\section{Authors:}

SEJRI NEJIB ${ }^{1}$, BOUSSAADOUN SLIM ${ }^{2}$, FAOUZI SAKLY ${ }^{1}$, GHAZI ELBICHE ${ }^{3}$

${ }^{1}$ Textile Engineering Laboratory, (HITS) of Ksar Hellal, Monastir University, Monastir, Tunisia e-mail: sejri.nejib@gmail.com, faouzi.sakli@isetkh.rnu.tn

${ }^{2}$ Vocational training and apprenticeship center of Bizerte, Tunisia

e-mail: slimbinz@gmail.com

${ }^{3}$ Tunisian Clothing Company, Bizerte, Tunisia

e-mail: gelbiche@topnet.tn

\section{Corresponding author:}

\section{SEJRI NEJIB}

e-mail: sejri.nejib@gmail.com 